\title{
A COMPARATIVE STUDY OF THE GONADO-SOMATIC INDEX (GSI) AND GONAD GROSS MORPHOLOGY OF AFRICAN CATFISH (Clarias gariepinus) FED UNICAL AQUA FEED AND COPPENS COMMERCIAL FEED
}

\author{
Victor Oscar Eyo ${ }^{*}$, Albert Philip Ekanem¹, Ufon-ima Udo Jimmy²
}

1 Institute of Oceanography, University of Calabar, P. M. B. 1115, Calabar, Nigeria

${ }^{2}$ Department of Fisheries and Aquaculture, Federal University of Agriculture, P. M. B. 2373, Makurdi, Benue State, Nigeria

* Corresponding Author, E-mail: sirvick2003@yahoo.com

\section{ARTICLE INFO}

Received: 13 August 2013

Received in revised form: 10 December 2013

Accepted: 30 December 2013

Available online: 28 January 2014

\section{Keywords:}

Clarias gariepinus

Gonad weight

Gonado-somatic index

Unical Aqua feed

Coppens commercial feed

\begin{abstract}
A comparative study of the gonado-somatic index (GSI) and gonad gross morphology of African catfish, Clarias gariepinus fed Unical Aqua feed and Coppens commercial feed was carried out for six months in concrete tanks. Two triplicate groups of 50 postfingerlings with a mean bulk weight of $0.50 \pm 0.02 \mathrm{~kg}$ were stocked in circular concrete tanks, area $16.63 \mathrm{~m}^{2}$ labeled $A_{1}, A_{2}, A_{3}, B_{1}, B_{2}$ and $B_{3}$. Fish in units $A_{1}, A_{2}$ and $A_{3}$ were fed Coppens feed while fish in units $B_{1}, B_{2}$ and $B_{3}$ were fed Unical Aqua feed twice daily at $3 \%$ of their body weights. Results obtained showed that mean gonad weight ( $99.03 \pm 16.57 \mathrm{~g}$ ) and the GSI ( $15.89 \pm 2.10 \%$ ) of female C. gariepinus fed Unical Aqua feed was not significantly different $(P>0.05)$ from fish fed Coppens feed with mean gonad weight ( $91.80 \pm 12.83 \mathrm{~g})$ and the GSI $(13.81 \pm 2.49 \%)$. In male fish fed Unical Aqua feed, mean gonad weight $(7.08 \pm 1.17 \mathrm{~g})$ and the GSI ( $1.16 \pm 0.30 \%)$ were not significantly different ( $P>0.05)$ from male fish fed Coppens feed with mean gonad weight (6.77 $\pm 1.09 \mathrm{~g})$ and the GSI $(1.12 \pm 0.32 \%)$. In female fish fed both feeds, there was a positive significant relationship between the GSI and total length, total weight and gonad weight. In male fish fed both feeds, there was also a positive non-significant $(P>0.05)$ relationship between the GSI and total length, total weight and gonad. Food conversion efficiency (FCE) was insignificantly higher $(\mathrm{P}>0.05)$ in fish fed Coppens feed $(50.94 \pm 0.91 \%)$ than fish fed Unical Aqua feed ( $50.37 \pm 1.29 \%)$. Histology of ovaries and testes of fish fed the two experimental diets showed normal development and distribution of oocytes and interstitial cells. Proximate analysis of the dry matter showed that moisture content, fat content, crude fibre content, ash content, carbohydrate and caloric value (C/V) differed significantly among experimental groups $(\mathrm{P}<0.05)$, while significant difference for crude protein content was not found $(\mathrm{P}>0.05)$. Physicochemical parameters were within acceptable range for fresh water fish culture. Based on these findings, Unical Aqua feed competed favorably with Coppens feed in terms of the GSI and gross gonad morphology of $C$. gariepinus and, on the basis of affordability, Unical Aqua feed is more economical and therefore recommended for fish farmers.
\end{abstract}

\section{INTRODUCTION}

African catfish (Clarias gariepinus) belonging to the family Clariidae is the most cultivated species in Nigeria. This could be attributed to its ability to tolerate a varying range of environmental conditions, high stocking densities under culture conditions, fast growth rate, disease resistance, acceptability of artificial feed, high fecundity, good taste and meat quality, ease of artificial breeding, high market value etc. According to FAO (2012), fish provides more than 1.5 billion people with almost 20 percent of their average per capita intake of animal protein, and 3.0 billion people with 
at least 15 percent of such protein.

Globally, aquaculture is consistent in providing a sustainable food source and income for man all year round. In Nigeria, its growth is hindered by lack of high quality feed which accounts for at least $60 \%$ of the total cost of fish production (Jamu and Ayinla, 2003). This has led to the importation of foreign feed such as Coppens, Vital, Podder feeds etc. The disadvantage of these imported feed is that they are very expensive and their supply is not consistent, especially in rural areas where most fish farms are located. This implies that profit margin of fish farmers will be compromised at the end of the culture period.

Gonads form micro environment enabling the germ cell to differentiate into ripe male and female gamete (Guraya, 2000). Gonad development has been reported to be greatly affected by nutrition in several fish species (Bromage and Roberts, 1995; Adewumi, 2005; Ekanem and Ekanem, 2010; Sotolu and Kigbu, 2011; Ekanem et al., 2012; Asuquo et al., 2012).

In an attempt to address high cost of feed and consistency in supply, the Education Thrust Fund (ETF) donated a multi-million naira feed mill to the University of Calabar fish farm. The objective of this study was to compare the gonado-somatic index (GSI) and morphological ratios among African Catfish (Clarias gariepinus) fed with Unical Aqua feed and Coppens commercial feed.

\section{MATERIALS AND METHODS}

\section{Study area}

This research was carried out at the Institute of Oceanography Fish Farm Hatchery complex, University of Calabar, which is geographically located within the historic peninsula between the Calabar River and the Great Kwa River with elevation of 41 meters above sea level. This area has latitude of $04^{\circ} 55.9^{\prime \prime} \mathrm{N}$ and longitude of $08^{\circ} 26^{\prime \prime} \mathrm{E}$ with a total surface area of three hectares $(3 \mathrm{Ha})$.

\section{Experimental design}

This research lasted for six (6) months and was carried out in the Hatchery complex of the Institute of Oceanography, University of Calabar, where 3 ETF circular concrete tanks of area $16.63 \mathrm{~m}^{2}$ were used. The three tanks were divided into two equal parts with hard wood covered with tapeline, each giving a total of six experimental units. The six units were labelled $A_{1}, A_{2}, A_{3}, B_{1}, B_{2}$ and $B_{3}$ to aid triplication of the experiment. Water volume in each unit was $\left(8.32 \mathrm{~m}^{3}\right)$. A total of 300 post fingerlings of $C$. gariepinus of mean weight (bulk) $0.50 \pm 0.00 \mathrm{~kg}$ ( $10 \mathrm{~g}$ for each post fingerling) were collected from the University of Calabar fish farm and stocked in each of the six experimental units (50 in each unit). The stocked fish were acclimated for seven days prior to the start of the feeding trial. During the acclimation period the fish were fed twice daily to satiation. At the start of feeding trial the acclimated fish were starved for 24 hours after which the average initial wet body weight of the fish in each experimental unit was measured using a METLAR MT-5000D electronic balance to the nearest gram (Eyo and Ekanem, 2011). Fish in units $A_{1}, A_{2}$ and $A_{3}$ were fed with Coppens feed, while fish in units $B_{1}, B_{2}$ and $B_{3}$ were fed Unical Aqua feed. Feeding was carried out twice daily (9:00 am and 4:00 pm) at 3\% of their body weight. Measurement of the fish body weight and gonad in each experimental unit was done at the end of the experiment. Physicochemical parameters like dissolved oxygen (DO), pH, ammonia and temperature were measured once weekly. Food conversion efficiency was determined as follows: Weight gain $(\mathrm{g}) /$ Feed consumed $(\mathrm{g}) * 100$, where food consumed is given as $3 \% \mathrm{x}$ body weight $\mathrm{x}$ Number of days.

\section{Coppens feed composition, characteristics and collection}

Coppens feed containing $42 \%$ crude protein is composed of high quality ingredients such as marine fish meal, calcium, phosphorus, lysine, methionine, copper sulphate $\left(\mathrm{CuSO}_{4}\right)$, selenium refined fish oil and several grains. The combination of these ingredients makes the feed extremely attractive for freshwater fish and also for the promotion of fast growth. Three sizes of Coppens feed ( $2 \mathrm{~mm}, 4 \mathrm{~mm}$ and $6 \mathrm{~mm}$ ) were purchased from a fish feed store in Calabar, Nigeria.

\section{Formulation, composition and preparation of Unical Aqua feed}

Unical Aqua feed is a product of University of Calabar fish feed mill. It was formulated using Pearson's square method to $42 \%$ crude protein level. Unical Aqua feed composition is shown in Table 1.

\section{Measurements of body parameters and gonad development}

At the end of the experiment, a total of one hundred and twenty male and one hundred and twenty female $C$. gariepinus (twenty from each experimental unit) were harvested from the experimental tanks and transported immediately to the Fisheries and Aquaculture laboratory, Institute of Oceanography, University of Calabar, for further analysis. Differentiation of sexes were based on external features (elongated genital papilla for male and around serrated opening for female) and internal features such as gonad.

The following body parameters were measured for each specimen: Total length (TL), Total weight (TW) and Gonad weight (GW). Total length was measured from snout to the base of the caudal fin rays. Measurements were taken to the nearest $0.1 \mathrm{~cm}$ and $0.1 \mathrm{~g}$ using measuring board for length and Metlar-2000D electronic weighing balance for weight. 
Croatian Journal of Fisheries, 2014, 72, $63-69$

V. O. Eyo et al.: Gonado-somatic index (GSI) and gonad gross morphology of African Catfish

Table 1. Unical feed composition in grams per kilograms

\begin{tabular}{lc}
\hline \hline Ingredients & $\begin{array}{c}\text { Composition in } \\
\text { grams }\end{array}$ \\
\hline Industrial fishmeal (IFM) & 244.4 \\
Groundnut meal (GNM) & 244.4 \\
Soybean meal (SBM) & 244.4 \\
Corn meal & 206.8 \\
Vitamin premix & 10 \\
Bone ash & 5 \\
Sodium chloride (NaCl) & 5 \\
Lysine & 5 \\
Wheat flour & 10 \\
Palm oil & 10 \\
Molasis & 20 \\
Methionine & 5 \\
\hline Total & $1000 \mathrm{~g}$
\end{tabular}

Gonadal development was determined using the gonadosomatic index (GSI) and was calculated using the formula below:

GSI = Gonad weight $(\mathrm{g}) /$ Whole fish weight $(\mathrm{g}) * 100$ (Bolger and Connolly, 1989)

For histological purpose, C. gariepinus gonads (female ovary and male testis) were extracted from fish fed with two experimental diets and were fixed in Bouin's fluid for 48 hours, manually processed and sectioned at $10 \mu$ with a rotary microtome, dewaxed in xylene, stained with haematoxylin and eosin standard method (Bancroft and Cook, 1994) for microscopic examinations.

\section{Proximate composition of Coppens and Unical Aqua feed}

Proximate analysis of the dry matter of Coppens and Unical Aqua feed was performed according to AOAC (2000) at the Department of Biochemistry, University of Calabar.

\section{Statistical analysis}

Using linear and power regressions, relationships between the gonado-somatic index (GSI) and body parameters (GSI/ TL-cm, GSI/TW-g and GSI/GW-g) for male and female $C$. gariepinus fed Coppens and Unical Aqua feed were determined. Data obtained from the gonado-somatic index, gross gonad morphology and food conversion efficiency (FCE) were subjected to T-test analysis for significant difference using Predictive Analytical Software (PASW) version 18.0. Effects with a probability of $(\mathrm{P}<0.05)$ were considered significant.

\section{RESULTS}

\section{Water quality parameters}

Water quality parameters measured in the present study showed that in experimental units fed Unical Aqua feed, mean $\mathrm{pH}$ ranged between $6.54 \pm 0.03$ to $7.31 \pm 0.08$, whereas in experimental units fed Coppens feed, $\mathrm{pH}$ ranged between $6.87 \pm 0.07$ to $7.24 \pm 0.17$. Mean dissolved oxygen ranged between $4.83 \pm 0.35 \mathrm{mg} / \mathrm{L}$ to $5.87 \pm 0.23 \mathrm{mg} / \mathrm{L}$ in experimental units fed Unical feed and $4.97 \pm 0.21 \mathrm{mg} / \mathrm{L}$ to $5.57 \pm 0.11 \mathrm{mg} / \mathrm{L}$ in experimental units fed Coppens feed. Mean water temperature ranged between $30.04 \pm 0.44{ }^{\circ} \mathrm{C}$ to $31.30 \pm 0.17{ }^{\circ} \mathrm{C}$ in experimental units fed Unical feed and $29.73 \pm 0.84{ }^{\circ} \mathrm{C}$ to $30.93 \pm 0.49{ }^{\circ} \mathrm{C}$ in experimental units fed Coppens feed. Mean ammonia ranged between $0.00 \pm$ $0.00 \mathrm{mg} / \mathrm{L}$ to $0.53 \pm 0.12 \mathrm{mg} / \mathrm{L}$ in experimental units fed Unical feed and $0.00 \pm 0.0 \mathrm{mg} / \mathrm{L}$ to $0.37 \pm 0.06 \mathrm{mg} / \mathrm{L}$ in units fed Coppens feed. Statistical analysis of water quality parameters did not differ significantly among experimental groups $(\mathrm{P}>0.05)$.

\section{Proximate composition of Coppens and Unical Aqua feed}

Mean proximate analysis of the dry matter (mg/100 g) of Coppens and Unical Aqua feed shows that moisture content was higher in Unical feed $(9.53 \pm 0.15)$ than Coppens $(8.23 \pm 0.07)$. Mean crude protein content was also higher in Unical feed $(43.30 \pm 0.23)$ than Coppens ( $42.94 \pm 1.34)$. Mean fat content also followed the same trend with Unical feed showing a higher value $(12.03 \pm 0.02)$ than Coppens feed $(11.57 \pm 0.15)$. Mean crude fibre content was higher in Coppens feed $(3.53 \pm 0.31)$ than Unical feed $(3.34 \pm 0.10)$. Mean ash content was higher in Coppens feed $(9.42 \pm 0.04)$ than Unical feed $(9.03 \pm 0.20)$. Mean carbohydrate content was higher in Coppens feed $(24.31 \pm 2.10)$ than Unical feed (22.77 \pm 1.27$)$.

\section{Food utilization of C. gariepinus fed Coppens and Unical Aqua feed}

Food utilization evaluated using food consumed and food conversion efficiency (FCE) showed that fish fed Coppens feed significantly consumed more food $(55.69 \pm 5.09 \mathrm{~kg})$ than fish fed Unical Aqua feed (48.84 $\pm 5.07 \mathrm{~kg})$. Food conversion efficiency ( $F C E)$ was insignificantly higher $(P>0.05)$ in fish fed Coppens feed $(50.94 \pm 0.91 \%)$ than fish fed Unical Aqua feed $(50.37 \pm 1.29 \%)$.

\section{Gonado-somatic index (GSI) of male C. gariepi- nus fed Coppens and Unical Aqua feed}

At the end of the experiment, mean female body weight for fish fed Unical Aqua feed was $628.93 \pm 109.46 \mathrm{~g}$, mean total length $(43.90 \pm 1.81 \mathrm{~cm})$, mean gonad weight $(99.03 \pm 16.57$ 
g) and the gonado-somatic index (15.89 $\pm 2.10 \%)$. Mean female body weight for fish fed Coppens feed was 673.28 $\pm 80.03 \mathrm{~g}$, mean total length $(43.80 \pm 2.58 \mathrm{~cm})$, mean gonad weight ( $91.80 \pm 12.83 \mathrm{~g}$ ) and the gonado-somatic index (13.81 $\pm 2.49 \%)$. T-Test analysis for gonad weight of female fish fed Coppens and Unical Aqua feed was insignificant with t-value of 1.395 , significant 2 -tailed value of 0.172 and $95 \%$ confidence interval of $-9.257 \mathrm{~g}$ to $1.724 \mathrm{~g}$. Similarly, T-Test analysis for the gonado-somatic index of female fish fed Coppens and Unical Aqua feed was also insignificant, with t-value of 1.247, significant 2-tailed value of 0.214 and $95 \%$ confidence interval of $-0.3034 \%$ to $1.336 \%$.

For males, mean body weight for fish fed Unical Aqua feed was $631.93 \pm 115.92 \mathrm{~g}$, mean total length $(48.03 \pm 3.11$ $\mathrm{cm})$, mean gonad weight $(7.08 \pm 1.17 \mathrm{~g})$ and the gonadosomatic index (1.16 $\pm 0.30 \%)$. Mean male body weight for fish fed Coppens feed was $629.40 \pm 110.82 \mathrm{~g}$, mean total length $(47.94 \pm 3.00 \mathrm{~cm})$, mean gonad weight $(6.77 \pm 1.09$ g) and the gonado-somatic index (1.12 $\pm 0.32 \%)$. T-Test analysis for gonad weight of male fish fed Coppens and Unical Aqua feed was insignificant with t-value of 1.532, significant 2-tailed value of 0.128 and $95 \%$ confidence interval of $-0.093 \mathrm{~g}$ to $0.726 \mathrm{~g}$. Similarly, T-Test analysis for the gonado-somatic index of male fish fed Coppens and Unical Aqua feed was also insignificant, with t-value of 0.750 , significant 2 -tailed value of 0.454 and $95 \%$ confidence interval of $-0.0687 \%$ to $0.153 \%$.

\section{Relationship between the gonado-somatic in- dex (GSI) and body parameters of $C$. gariepinus fed Coppens and Unical Aqua feed}

The gonado-somatic index (GSI) of female C. gariepinus fed Unical Aqua feed showed a linear relationship with the total length $(\mathrm{cm})$, total weight $(\mathrm{g})$ and gonad weight $(\mathrm{g})$. Power regression equation for the gonado-somatic index (GSI) and total length $(\mathrm{cm})$, total weight $(\mathrm{g})$ and gonad weight $(\mathrm{g})$ of female C. gariepinus fed Unical Aqua feed is as follows:

$$
\begin{aligned}
& \mathrm{GSI}=345.68 \mathrm{TL}^{-0.817}\left(r=0.2567 \text { and } r^{2}=0.0659, \mathrm{P}>0.05\right) \\
& \mathrm{GSI}=133.86 \mathrm{TW}^{-0.333}\left(\mathrm{r}=0.4269 \text { and } \mathrm{r}^{2}=0.1822, \mathrm{P}>0.05\right) \\
& \mathrm{GSI}=4.141 \mathrm{GW}^{0.2917}\left(\mathrm{r}=0.3632 \text { and } \mathrm{r}^{2}=0.1319, \mathrm{P}>0.05\right)
\end{aligned}
$$

The gonado-somatic index (GSI) of female $C$. gariepinus fed Coppens feed showed a linear relationship with the total length $(\mathrm{cm})$, total weight $(\mathrm{g})$ and gonad weight $(\mathrm{g})$. Power regression equation for the gonado-somatic index (GSI) and total length $(\mathrm{cm})$, total weight $(\mathrm{g})$ and gonad weight $(\mathrm{g})$ of female $C$. gariepinus fed Coppens feed as shown in Figure 4, 5 and 6 is as follows:

$$
\begin{aligned}
& \text { GSI }=2799 \mathrm{TL}^{-1.410}\left(r=0.4957 \text { and } r^{2}=0.2457, P>0.05\right) \\
& \text { GSI }=5038.2 W^{-0.909}\left(r=0.5878 \text { and } r^{2}=03544, P>0.05\right) \\
& G S I=0.1959 \mathrm{GW}^{0.9401}\left(r=0.7574 \text { and } r^{2}=0.5737, P>0.05\right)
\end{aligned}
$$

The gonado-somatic index (GSI) of male $C$. gariepinus fed
Unical Aqua feed showed a linear relationship with the total length $(\mathrm{cm})$, total weight $(\mathrm{g})$ and gonad weight $(\mathrm{g})$. Power regression equation for the gonado-somatic index (GSI) and total length $(\mathrm{cm})$, total weight $(\mathrm{g})$ and gonad weight $(\mathrm{g})$ of male C. gariepinus fed Unical Aqua feed is as follows:

$$
\begin{aligned}
& \text { GSI }=39321 \mathrm{TL}^{-2.704}\left(r=0.6663 \text { and } r^{2}=0.4439, P>0.05\right) \\
& G S I=658.54 W^{-0.991}\left(r=0.7268 \text { and } r^{2}=0.5283, P>0.05\right) \\
& G S I=0.1643 W^{0.9898}\left(r=0.6799 \text { and } r^{2}=0.4622, P>0.05\right)
\end{aligned}
$$

The gonado-somatic index (GSI) of male $C$. gariepinus fed Coppens feed showed a linear relationship with the total length $(\mathrm{cm})$, total weight $(\mathrm{g})$ and gonad weight $(\mathrm{g})$. Power regression equation for the gonado-somatic index (GSI) and total length $(\mathrm{cm})$, total weight $(\mathrm{g})$ and gonad weight $(\mathrm{g})$ of male C. gariepinus fed Coppens feed is as follows:

$$
\begin{aligned}
& \text { GSI }=377225 \mathrm{TL}^{-3.3}\left(r=0.7699 \text { and } r^{2}=0.5928, P>0.05\right) \\
& G S I=2007.4 W^{-1.171}\left(r=0.8136 \text { and } r^{2}=0.6620, P>0.05\right) \\
& G S I=0.1035 W^{1.2346}\left(r=0.7326 \text { and } r^{2}=0.5367, P>0.05\right)
\end{aligned}
$$

\section{Histology of C. gariepinus gonads fed Unical and Coppens feed}

The results of the histology of ovaries and testes of fish fed Coppens and Unical Aqua feed showed normal distribution of cells in their developments. The oocytes were fully matured in C. gariepinus fed both experimental diets (Plate 1 and 2). Similarly, the interstitial cells of the testes of $C$. gariepinus fed both experimental diets showed normal testicular cells (Plate 3 and 4).

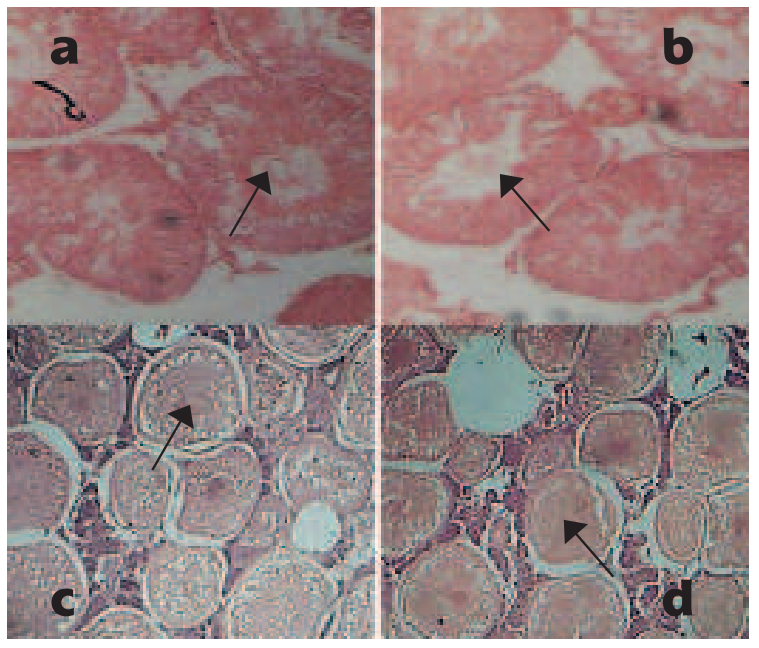

a. Photomicrograph of testis of $C$. gariepinus fed Unical feed showing normal testicular cells (X10)

b. Photomicrograph of testis of $C$. gariepinus fed Coppens feed showing normal testicular cells (X10)

c. Photomicrograph of ovary of $C$. gariepinus fed Unical feed showing normal oocytes (X10)

d. Photomicrograph of ovary ofC. gariepinus fed Coppens feed showing normal oocytes (X10) 


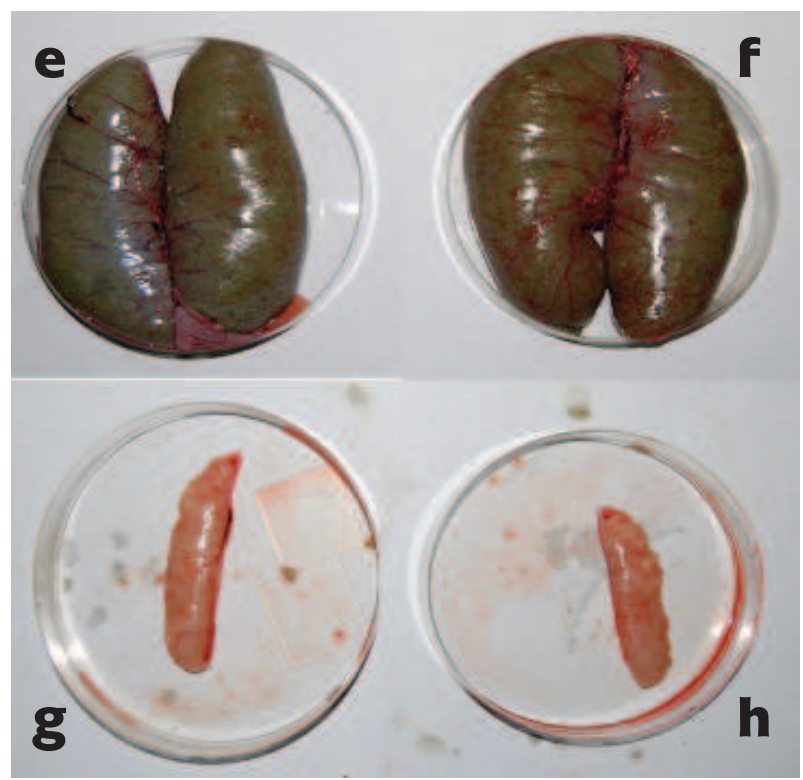

e. Ovary of C. gariepinus fed Unical Aqua feed using digital camera

f. Ovary of C. gariepinus fed Coppens feed using digital camera g. Testis of $C$. gariepinus fed Unical feed using digital camera h. Testis of $C$. gariepinus fed Coppens feed using digital camera

\section{DISCUSSION}

Results obtained in the present study indicate that utilization of good quality feeds plays a major role in gonad development in C. gariepinus. According to Guraya (1994), differentiation of spermatogonia and oogonia into mature spermatozoa and sperm cell occurs in adult fish. Before sex differentiation in fish, the undifferentiated gonad contains all the cell types required to make it capable of developing into either a testis or an ovary (Francis, 1992). The study indicated that sub-adults of C. gariepinus had developed gonad (matured) between 6 to 8 months under standard outdoor circular concrete tank conditions with a natural photoperiod ( $12 \mathrm{~h}$ light and $12 \mathrm{~h}$ dark). Environmental factors such as temperature, photoperiod, nutrient supply, dissolved oxygen, disease (parasites) etc. are observed to influence gametogenesis (process by which gamete [egg and sperm] are produced from the gonia of matured gonad during reproductive cycle in fish) (Maitra, 1997; Joy et al., 1992). Thus, their effective management is important for productive aquaculture, especially in relation to broodstock management and egg and larval quality (Horwood, 1993; Bromage and Roberts, 1995). In the present study, physicochemical parameters including $\mathrm{pH}$, dissolved oxygen, water temperature were maintained at optimum level as recommended by Boyd (1979) for freshwater fish culture. It was observed in this study that maturation in male C. gariepinus (development of genitals papilla and spermatozoa) was first detected at 4 months of culture. Early maturation in fish has been achieved either by genetic selection or better nutrition, revealing a correlation between maturation and growth (Le Bail, 1996). Full maturation of $C$. gariepinus was found to be 10 months of age in fish fed both Unical and Coppens feed which agrees with the findings of Cek and Yilmaz (2005). In the present study, the mean gonado-somatic index of both male and female $C$. gariepinus fed Unical Aqua feed was not significantly different from fish fed Coppens feed. The gonadal development of fish fed the two experimental diets is an indication that the two feeds have met the nutritional requirements of $C$. gariepinus broodstock in a culture system without any insignificant variation between them.

In the present study, food conversion efficiency (FCE) was insignificantly higher in fish fed Coppens feed than fish fed Unical Aqua feed. FCE of fish fed Coppens (50.94 $\pm 0.91 \%$ ) and Unical Aqua feed $(50.37 \pm 1.29 \%$ ) falls within the range (above $50 \%$ ) considered as good growth in fish culture (Ndome et al., 2011). This finding is similar to Ekanem et al. (2012) who reported that C. gariepinus responded positively to Unical feed and Coppens feed in terms of growth performance indices such as weight gain, length gain, specific growth rate and mean growth rate. Gonad development was not observed to be affected by body size in both male and female fish fed the two experimental diets. For instance, the highest gonad weight of $148 \mathrm{~g}$ was recorded in female fish fed Unical diet with body weight of $762 \mathrm{~g}$, whereas fish with the highest body weight (832 g) had gonad weight of $132 \mathrm{~g}$. A similar observation was also found in female fish fed Coppens feed where female fish weighing $763 \mathrm{~g}$ had the highest gonad weight of $119 \mathrm{~g}$, whereas fish with the highest body weight (843 g) had gonad weight of $94 \mathrm{~g}$. However, a similar observation was also found in male $C$. gariepinus fed both experimental diets. These findings are similar to Schulz et al. (1994) who stated that maturity is related to age in C. gariepinus and disagrees with Cek and Yilmaz (2005) whose observations showed that maturity was related to size rather than age. Also, findings from the present study counter earlier reports by El-Sayed et al. (2003) and Chong et al. (2004) who related body size to maturation of gonads and early occurrence of egg in larger broodstocks. Different types of relationships were observed between gonado-somatic development and body parameters such as male/female body weight (MBW/ FBW), male/female gonad weight (MGW/FGW) and male/ female body weight (MBW/FBW). In this study, the gonadosomatic index of both male and female $C$. gariepinus fed Coppens and Unical Aqua feed showed a non-significant positive correlation with body parameters including male/female body weight (MBW/FBW), male/female gonad weight (MGW/FGW) and male/female body weight (MBW/FBW). These findings disagree with Akpaniteaku (2012) who reported a significant relationship between total length and total weight of C. gariepinus and size of their gonads. Results from this study corroborate with Sotolu and Kigbu (2011) who reported that increased dietary protein level of catfish diet up to $40 \%$ would produce high gonadal development. This finding is also similar to the findings of Sotolu (2010) who observed that performance of catfish broodstock can be affected by dietary protein level. Gu- 
nasekera et al. (1996) and Muchlisin et al. (2006) also reported that increasing dietary crude protein contents resulted in high values of fish egg weight. However, utilization of the two experimental diets by the experimental fish stimulated an early maturation as observed in their gonadal development within 6 months of culture. This agrees with Eyo and Ekanem (2011) who reported that nutrients must be able to be digested and absorbed in a form that makes them available for providing energy and substrate for growth (bioavailability). The histology of the gonad (ovaries and testes) of $C$. gariepinus fed the two experimental feeds in this study showed normal distribution of oocytes and interstitial cells. Results obtained from the present study agree with the findings of Adewumi (2005) who reported faster gonadal development in fish fed diet with animalbased ingredients. Also, Cek and Yilmaz (2005) and Ekanem and Ekanem (2010) attributed better development of gonads to high quality feed.

\section{SUMMARY AND CONCLUSION}

The present study has shown that Unical Aqua feed competed favorably with Coppens feed in terms of the gonado-somatic index and gross gonad morphology of $C$. gariepinus. The implication of the result is that Unical Aqua feed have met the nutritional requirements of $C$. gariepinus broodstock in a culture system. On the basis of affordability, Unical Aqua feed is more economical (about 50\% the cost of Coppens feed) and is hereby recommended for the production of $C$. gariepinus broodstock.

\section{Sažetak}

\section{USPOREDNO ISTRAŽIVANJE GONADOSO- MATSKOG INDEKSA (GSI) I MORFOLOGIJE GONADA AFRIČKOG SOMA (Clarias gariepi- nUs) HRANJENOG UNICAL AQUA HRANOM I KOMERCIJALNOM HRANOM PROIZVOĐAČA COPPENS}

Usporedno istraživanje gonadosomatskog indeksa (GSI) i morfologije gonada afričkog soma, C. gariepinus, hranjenog Unical Aqua hranom i komercijalnom hranom proizvođača Coppens, provedeno je tijekom šest mjeseci u betonskim spremnicima. Dvije trostruke skupine od 50 jedinki mlađi prosječne težine $0,50 \pm 0,02 \mathrm{~kg}$ pohranjene su u kružnim betonskim spremnicima površine $16,63 \mathrm{~m}^{2}$, s oznakama $A_{1}, A_{2}, A_{3}, B_{1}, B_{2}$ i $B_{3}$. Riba u jedinicama $A_{1}, A_{2}$ i $A_{3}$ hranjena je hranom proizvođača Coppens, a riba u jedinicama $\mathrm{B}_{1}, \mathrm{~B}_{2}$ i $\mathrm{B}_{3}$ hranjena je Unical Aqua hranom dvaput dnevno na $3 \%$ svoje tjelesne težine. Dobiveni rezultati su pokazali da srednja težina gonada $(99,03 \pm 16,57$ g) i GSI indeks $(15,89 \pm 2,10 \%)$ ženke $C$. gariepinus hranjene Unical Aqua hranom nisu bili značajno različiti $(\mathrm{P}>0,05)$ od težine ribe hranjene hranom proizvođača Coppens, čija je sred- nja težina gonada bila $91,80 \pm 12,83 \mathrm{~g}$, a GSI indeks 13,81 $\pm 2,49 \%$. Kod mužjaka ribe hranjene Unical Aqua hranom, prosječna težina gonada bila je 7,08 $\pm 1,17 \mathrm{~g}$, a GSI indeks $1,16 \pm 0,30 \%$, što se neznatno razlikuje od vrijednosti kod mužjaka ribe hranjene hranom proizvođača Coppens, čija je prosječna težina bila $6,77 \pm 1,09 \mathrm{~g}$, a GSI indeks $1,12 \pm$ $0,32 \%$. Kod ženki hranjenih i jednom i drugom hranom uočena je pozitivna značajna povezanost između GSI indeksa i ukupne dužine, ukupne težine i težine gonada. Kod mužjaka hranjenih i jednom i drugom hranom također je uočena pozitivna, ali neznačajna $(P>0,05)$ povezanost između GSI indeksa i ukupne dužine, ukupne težine i težine gonada. Hranidbena iskoristivost (FCE) neznatno je veća $(P>0,05)$ kod ribe hranjene hranom proizvođača Coppens (50,94 $\pm 0,91 \%)$ u odnosu na ribu hranjenu Unical Aqua hranom (50,37 $\pm 1,29 \%)$. Histologija jajnika i testisa kod ribe podvrgnute dvjema eksperimentalnim dijetama pokazala je normalan razvoj i distribuciju jajnih i intersticijskih stanica. Približna analiza suhe tvari pokazala je značajnu razliku između sadržaja vlage, masti, sadržaja sirovih vlakana, sadržaja pepela, ugljikohidrata i kalorijske vrijednosti (C/V) u eksperimentalnim grupama $(P<0,05)$, a kod sadržaja proteina nije pronađena značajna razlika $(P>0,05)$. Fizikalnokemijski parametri bili su unutar prihvatljivih granica za uzgoj slatkovodnih riba. Na temelju ovih nalaza, Unical Aqua hrana i hrana proizvođača Coppens su prilično slične po svom učinku na GSI indeks i morfologiju gonada C. gariepinus, jedino je u smislu dostupnosti Unical Aqua hrana ekonomičnija i stoga se preporučuje uzgajivačima ribe.

Ključne riječi: Clarias gariepinus, težina gonada, gonadosomatski indeks, Unical Aqua hrana, komercijalna hrana proizvođača Coppens

\section{REFERENCES}

Adewumi, A. A. (2005): The effects of the heating time of soybean for broodstock nutrition on the reproductive performance of C. gariepinus (Burchell 1822). Unpublished Ph.D Thesis, Obafemi Awolowo University, lle Ife, Nigeria, $162 \mathrm{p}$.

Akpaniteaku, R. C. (2012): The Relationship Between Sizes of African Catfish (Clarias gariepinus) Spawners and Their Ovaries. International Journal of Water and Soil Resources Research, 3, 1, 9- 14 .

AOAC (2000): Association of Official Analytical Chemists International (AOAC). Official methods of analysis, 17th ed. AOAC International, Gaithersburg, MD, USA.

Asuquo, P. E., Ekanem, A. P., Eyo, V. O., Pedro, E. J. (2012): Effects of diets with Cassav leaf meal (CLM) Manihot utilissima on the growth and fecundity of Clarias gariepinus. African Journal of Bioscience, 5, 1, 49 - 53.

Bancroft, J. D., Cook, H. C. (1994): Manual of histopathological techniques and their diagnostic application. Churchill Livingstone, London, pp. 305.

Bolger, J., Connolly, P. L. (1989): The selection of suitable 
indices for the measurement and analysis of fish condition. Journal of Fish Biology, 34, 171- 182.

Boyd, C. E. (1979): Water Quality in Warmwater Fish Ponds. Auburn University Agriculture Experiment Station, Auburn, Alabama.

Bromage, N. R., Roberts, R. J. (1995): Broodstock Management and Egg and Larval Quality. Osmead, Oxford, UK: Blackwell Science, $25-52$.

Cek, S., Yilmaz, E. (2005): Gonad Development and Sex Ratio of Sharptooth Catfish (Clarias gariepinus Burchell, 1822) Cultured under Laboratory Conditions. Turkish Journal of Zoology, 31, 2007, $35-46$.

Chong, A. S. C., Ishak, S. D., Osman, Z., Hashim, R. (2004): Effect of dietary protein level on the reproductive performance of female swordtails Xiphophorus helleri (Poecciliidae). Aquaculture, 234, 381 - 392.

Ekanem, A. P., Ekanem, I. E. (2010): Effects of phyto-protein and normal diet on the growth and Gonadal development of Clarias gariepinus. Tropical Environmental Research, 9, $556-559$.

Ekanem, A. P., Eteng, S. U., Nwosu, F. M., Eyo, V. O. (2012): Comparative Study of the Growth and Gonad Development of Clarias gariepinus (Burchell 1822) Fed Diets with Plant and Animal-based Ingredients in Concrete Tanks. Journal of Agricultural Science and Technology, 2, 1203-1210.

El-Sayed, A. M., Mansour, C. R., Ezzat, A. A. (2003): Effects of dietary protein level on spawning performance of Nile tilapia (Oreochromis niloticus) broodstock reared at different water salinities. Aquaculture, 220, $619-632$.

Eyo, V. O., Ekanem, A. P. (2011): Effect of feeding frequency on the growth, food utilization and survival of African catfish (Clarias gariepinus) using locally formulated diet. African Journal of Environmental Pollution and Health, 9, 2, $11-17$.

FAO (2012): The state of the world fisheries and aquaculture. Food and Agriculture Organisation of the United Nation, Rome, pp $3-41$.

Francis, R. C. (1992): Sexual lability in teleosts: Developmental factors. Quast Revolutionary Biology, 67, 1 - 18.

Gunasekera, R. M., Shim, K. F., Lam, T. J. (1996): Influence of protein content of broodstock diet on larval quality and performance in Nile tilapia (Oreochromis niloticus). Aquaculture, 146, 245 - 259.

Guraya, S. S. (1994): Gonadal development and production of gametes in fish; Proceedings of Indian national Science Academy (PINSA), B60, 15 - 32.
Guraya, S. S. (2000): The biology of gonad development, sex differentiation and maturation and sex reversal in fish: Cellular, molecular and Endocrinological aspects. Proceedings of Indian national Science Academy (PINSA), B60, 4 - 5 .

Horwood, J. (1993): The Bristol channel sole; Solea solea (L.): A fisheries case study. Advances in Marine Biology, 29, $215-267$.

Jamu, D. M., Ayinla, O. A. (2003): Potential for the development of aquaculture in Africa. NAGA, 26, 9 - 13.

Joy, K. P., Krishna, A., Haldar, C. (1992): Comparative Indocrinology and Reprouctive. New Delhi, Narosa.

Le Bail, P. Y. (1996): Growth-reproduction interaction in salmonids. In: Zohar, Y. and Breton, B. (Eds.), Reproduction in Fish, Basic and Applied Aspects in Endocrinology and Genetics. Paris, Les Colloques de IÕINRA, 91 - 107.

Maitra, S. K. (1997): Frontiers in Environmental and Metabolic Endocrinology (Burdwan, West Bengal: The University of Burdwan).

Muchlisin, Z. A., Hashim, R., Chong, A. S. C. (2006): Influence of dietary protein levels on growth and egg quality in broodstock female Bagrid catfish (Mystus nemurus Cuv. and Val.). Aquaculture Research, 37, 416 - 418.

Ndome, C. B., Ekwu, A. O., Ateb, A. A. (2011): Effect of Feeding Frequency on Feed Consumption, Growth and Feed Conversion of Clarias gariepinus X Heterobranchus Iongifilis Hybrids. American-Eurasian Journal of Scientific Research, 6, 1, 6- 12.

Schulz, R. W., Vander-Corput, L., Janssen-Dommerholt, J., Goos, H. J. T. (1994): Sexual steroids during puberty in male African catfish (Clarias gariepinus): serum levels and gonadotropin stimulated testicular secretion in vitro. Journal of Contemporary Physiology, 164, 195 - 205.

Sotolu, A. O. (2010): Feed utilization and biochemical characteristics of Clarias gariepinus (Burchell, 1822) fingerlings fed diets containing fish oils and vegetable oils as total replacements. World Journal of Fish and Marine Science, 2, 2, 93 - 98.

Sotolu, A. O., Kigbu, A. A. (2011): Growth and Gonad Quality of Clarias gariepinus (Burchell, 1822) Broodstock Fed Varying Dietary Protein Levels. Pakistan Journal of Aquaculture, 7, 2, $61-67$. 